\title{
A CASE STUDY OF OZONE PRODUCTION IN A RURAL AREA OF CENTRAL ONTARIO
}

\author{
X. Lin, ${ }^{*}$ O. T. Melo,* D. R. Hastie, $†$ P. B. Shepson, $†$ H. Niki $\dagger$ and \\ J. W. BotTENHEIM † \\ *Research Division, Ontario Hydro, Toronto, Ontario, Canada, †Department of Chemistry and Centre for \\ Atmospheric Chemistry, York University, North York, Ontario, Canada and łAtmospheric Environment \\ Service, Environment Canada, Downsview, Ontario, Canada
}

\begin{abstract}
An}_{3}$ episode observed at Dorset, a rural site in central Ontario, during a stagnant high pressure period of the intensive Eulerian Model Evaluation Field Study (EMEFS), in the summer of 1988, is simulated using a photochemical box model with a two-layer treatment. In the model analysis, natural hydrocarbon chemistry is simulated based on an isoprene-only scenario. Sensitivity tests indicate that local isoprene emissions are an important contributor to local $\mathrm{O}_{3}$ production, relative to anthropogenic hydrocarbons (AHCs), during the event.

The model calculated isoprene contribution to the local $\mathrm{O}_{3}$ production, defined as the ratio of the $\mathrm{O}_{3}$ amount formed in the absence of AHCs to that in the presence of AHCs, is characterized by a strong NO, dependence. A minimum value $(\sim 50 \%)$ of the contribution was found at a $\mathrm{NO}_{x}$ level of $\sim 6 \mathrm{ppbv}$ for the representative hydrocarbon composition during the episode. At this $\mathrm{NO}_{x}$ level, $\mathrm{O}_{3}$ production was strongly influenced by the presence of AHCs. At significantly higher or lower $\mathrm{NO}_{x}$ levels, isoprene is more important than AHCs in the local $\mathrm{O}_{3}$ production.
\end{abstract}

Key word index: Anthropogenic hydrocarbons, natural hydrocarbons, isoprene, $\mathrm{O}_{3}$ production.

\section{INTRODUCTION}

Frequent occurrences of high $\mathrm{O}_{3}$ concentrations in the U.S. and Canada continue to be of great concern. Multiday $\mathrm{O}_{3}$ episodes, extending over large $\left(>6,000,000 \mathrm{~km}^{2}\right)$ areas of eastern North America are observed 5-10 times a year (Logan, 1989). The 1-h Canadian National Ambient Air Quality acceptable level for $\mathrm{O}_{3}(82 \mathrm{ppbv})$ is exceeded more than $150 \mathrm{~h}$ per year at sites in Ontario near the lower Great Lakes (OME, 1990). Air pollution monitoring at Dorset, a rural site in central Ontario, indicates that even at sites relatively distant from anthropogenic emission sources the Canadian standard is exceeded quite frequently $(121 \mathrm{~h}$ in 1988 and $20 \mathrm{~h}$ in 1983; Modelling Workgroup, 1990).

Concern over $\mathrm{O}_{3}$ (as well as acidic deposition) prompted the development in Canada (with involvement by F.R.G. and the Electric Power Research Institute) of the Acid Deposition and Oxidant Model (ADOM) in the early 1980s (Venkatram et al., 1988). At the same time, the U.S. proceeded with the development of RADM, the Regional Acid Deposition Model (Chang et al., 1987). Both models are designed to assess source-receptor relationships, using an Eulerian framework and detailed description of photochemistry. One of the important steps in the development of both models involves the evaluation of the models against observations. A 2-year field study, the Eulerian Model Evaluation Field Study (EMEFS) was launched in June 1988 to provide the data required for the evaluation (Puckett et al., 1991).
Included in the EMEFS project was an intensive measurement program at six highly instrumented sites in the U.S. and Canada. The program at the two Canadian sites (Egbert and Dorset, Ontario) was coordinated by the Canadian Institute for Research in Atmospheric Chemistry (CIRAC), and involved the Atmospheric Environment Service of Environment Canada, Concord Scientific Corporation, Ontario Hydro, The Ontario Ministry of the Environment, Unisearch Associates and York University. The program involved measurement of a number of key chemical species, meteorological parameters and solar radiation at the two ground stations and from aircraft flying between them. In addition to supporting the goals of EMEFS, this data set provides a unique opportunity to study the relevant atmospheric processes involved in regional and local $\mathrm{O}_{3}$ episodes in central Ontario.

Previous studies have shown that, on a large scale, the emission of natural hydrocarbons dominates the emission of anthropogenic hydrocarbons. Zimmerman (1979) estimated that $15 \mathrm{Mt}$ of isoprene and $50 \mathrm{Mt}$ of monoterpenes are emitted annually in the U.S. In 1985, the total amount of hydrocarbons emitted from anthropogenic sources in the U.S. was about $22.3 \mathrm{Mt}$ (Zimmerman et al, 1988a). An inventory by Lamb et al. (1987) indicated that the total emission of natural hydrocarbons (NHCs) is as large as or larger than that of anthropogenic hydrocarbons (AHCs) on regional scales, consistent with the estimates of Zimmerman. According to their study, $63 \%$ of the total non-methane hydrocarbon (NMHC) emis- 
sion in the U.S. is of natural origin. A similar situation is thought to exist in Canada, even though emission rates of NHCs are highly dependent on temperature. For example, the emission of NHCs in Ontario was estimated to be about twice that of AHCs in 1980 (OME, 1984).

NHCs are more reactive than most of the AHCs under atmospheric conditions typically encountered at rural sites. For example, at $300 \mathrm{~K}$, the rate coefficient for the reaction of isoprene with $\mathrm{OH}$ is $9.2 \times 10^{-11} \mathrm{~cm}^{3}$ molecule ${ }^{-1} \mathrm{~s}^{-1}$ while the rate coefficients for propane, $n$-butane and propylene are $1.3 \times 10^{-12}, 2.7 \times 10^{-12}$ and $2.5 \times 10^{-11} \mathrm{~cm}^{3}$ molecule ${ }^{-1} \mathrm{~s}^{-1}$, respectively (IUPAC, 1989). Therefore, the potential of NHCs to generate secondary pollutants, such as $\mathrm{O}_{3}, \mathrm{PAN}$, etc, is expected to be significant in the tropospheric photochemical system even though their concentrations may be lower than those of AHCs.

In earlier studies (Altshuller, 1983; Lurmann et al., 1983, 1984), it was generally concluded that the impact of NHCs on tropospheric $\mathrm{O}_{3}$ production was small. Altshuller (1983) found that NHCs did not contribute substantially to the formation of $\mathrm{O}_{3}$ in ambient air, based on information on the ratios of $\mathrm{O}_{3}$ produced to hydrocarbons consumed. In a trajectory modelling study, it was shown that NHC emission contributed little to the maximum $\mathrm{O}_{3}$ concentration and only 2-11 ppbv (2-9\%) of the predicted maximum $\mathrm{O}_{3}$ was due to natural emissions in the Tampa/St Petersburg region of Florida (Lurmann et al., 1984).

More recently, Trainer et al. $(1987 \mathrm{~b}, 1991)$ used a one-dimensional PBL photochemical model to successfully simulate $\mathrm{O}_{3}$ concentrations measured at Scotia, PA, a rural site in the eastern U.S., during a high $\mathrm{O}_{3}$ episode in the summer of 1986. They found that $\mathrm{NHCs}$ played a dominant role over AHCs in $\mathrm{O}_{3}$ production during the 4-day meteorologically stag-

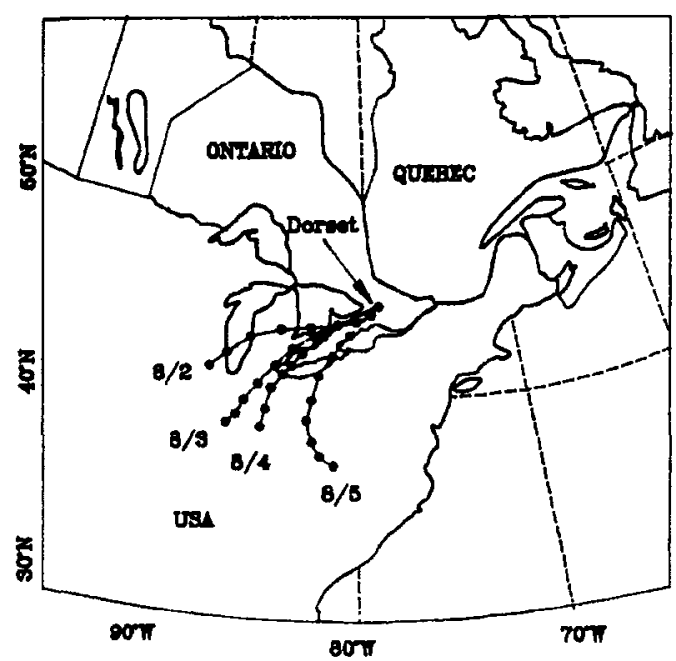

Fig. 1. Forty-eight hour back trajectories at $925 \mathrm{mb}$ for $1400 \mathrm{~h}$ local time on 2-5 August 1988. nant period. The calculated $\mathrm{O}_{3}$ levels without $\mathrm{AHCs}$ accounted for more than $90 \%$ of the total $\mathrm{O}_{3}$ predicted in the baseline run with both natural and anthropogenic emissions included. Chameides et al. (1988) studied the role of biogenic hydrocarbons in the Atlanta metropolitan area. Their calculations, performed with a city-specific empirical kinetics modelling approach (EKMA), indicated that, even in an urban area, natural emissions can significantly affect $\mathrm{O}_{3}$ levels and the presence of NHCs can exert a profound influence on the effectiveness of an $\mathrm{O}_{3}$ abatement strategy based on AHC reductions.

In the present study, simulations of measurement data, obtained at the Dorset, Ontario site of the Ontario Ministry of the Environment during an $\mathrm{O}_{3}$ episode which occurred in the first week of August 1988, were conducted. The concurrently measured levels of primary pollutants (hydrocarbons and $\mathrm{NO}_{x}$ ), temperature and solar radiation were used as inputs to a photochemical box model with a two-layer treatment. Calculated secondary pollutant concentrations $\left(\mathrm{O}_{3}\right.$ and formaldehyde) are compared with the observed values. The relative role of NHCs vs AHCs in oxidant production during the episode is investigated. Factors affecting the importance of $\mathrm{NHCs}$ in $\mathrm{O}_{3}$ production at Dorset, Ontario during this episode are also discussed.

\section{MEASUREMENTS AND MODEL DESCRIPTION}

The Dorset site is an Acid Precipitation in Ontario Study (APIOS) monitoring site maintained by the Ontario Ministry of the Environment, located in a rural forested area of central Ontario $\left(45^{\circ} 13^{\prime} \mathrm{N} ; 78^{\circ} 55^{\prime} \mathrm{W}\right)$, elevation $320 \mathrm{~m}$. A small town (Dorset), population $<1000$, is located $4 \mathrm{~km}$ to the NE. There are no significant local point sources of AHCs or NO. The monitoring site is in a valley with a hill (elevation $387 \mathrm{~m}$ ) $100 \mathrm{~m}$ to the SW. The site is also surrounded by hilltops $\sim 500 \mathrm{~m}$ to the NW (elevation $385 \mathrm{~m}$ ), $\sim 500 \mathrm{~m}$ to the NE (elevation $401 \mathrm{~m}$ ), and $\sim 1000 \mathrm{~m}$ to the $S$ (elevation $409 \mathrm{~m}$ ). The local land is $88 \%$ forested ( $75 \%$ deciduous, $25 \%$ coniferous) and $10 \%$ water.

From 2 to 5 August 1988 the whole of southern and central Ontario was under the influence of a stationary high pressure system. This produced daily maximum temperatures above $33^{\circ} \mathrm{C}$. The air flow to Dorset, as determined from isobaric back trajectories, was from the SW throughout this period. Forty-ight hour back trajectories $(925 \mathrm{mb})$ for $1400 \mathrm{~h}$ (local time) for these 4 days are shown in Fig. 1, which also indicates the location of the site in central Ontario.

In situ measurements were made for formaldehyde, NO temperature and u.v. radiation. Formaldehyde was measured by Tunable Diode Laser Absorption Spectrometry (TDLAS) with the data reported as 30 -min averages. The TDLAS formaldehyde data were in reasonable agreement with simultaneous measurements conducted by DNPH/HPLC (Shepson et al, 1991). Harris et al. (1989) detail the procedures for sampling and calibration for an identical configuration and report an instrument accuracy of $\pm 20 \%$. The precision of each measurement in the data presented here was estimated, from the statistics of the routine used to extract the data, to be better than $10 \%$. $\mathrm{NO}_{x}$ data were from a luminol-based $\mathrm{NO}_{2}$ analyser (Unisearch/Scintrex Model LMA-3) equipped with a chromium trioxide $\left(\mathrm{CrO}_{3}\right)$ converter for $\mathrm{NO}_{x}$ measurements. These data were corrected for instrument non-linear- 


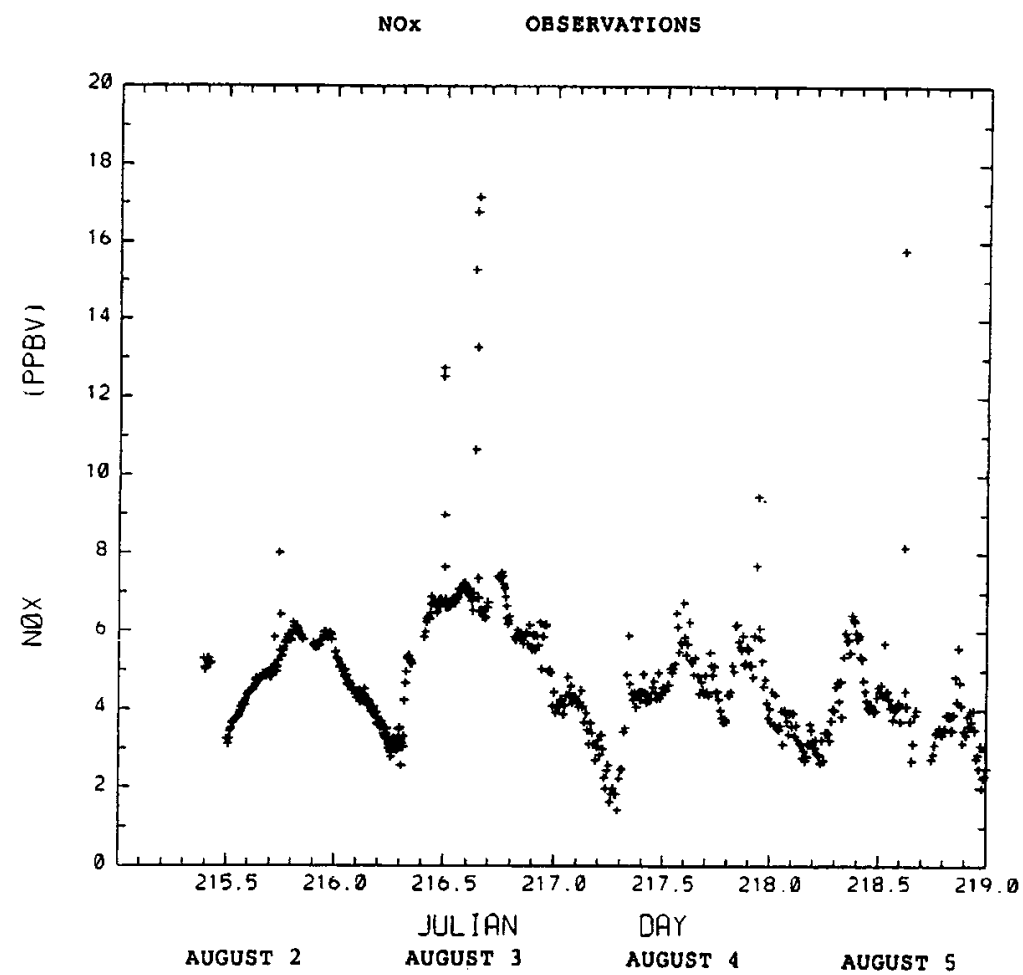

Fig. 2. Measured $\mathrm{NO}_{x}$ levels at Dorset, Ontario during 2-5 August 1988.

ity and known PAN and $\mathrm{O}_{3}$ interferences. Since the measured $\mathrm{NO}_{x}$ levels were relatively high and PAN concentrations were quite low ( $\sim 0.15 \mathrm{ppbv}$ on average), these corrections were small and did not influence the measurement accuracy, which was dominated by the calibration source and was estimated at $\pm 20 \%$. The instrument measured $\mathrm{NO}_{2}$ and $\mathrm{NO}_{x}$ over 5-min periods, sequentially, so the $\mathrm{NO}_{x}$ data used here are 5 -min averages over a $10-$ min interval. Ozone was measured with a Dasibi model AH-1008 u.v. absorption analyser, for which we estimate an absolute uncertainty of $\pm 10 \%$. Temperature was measured with a Met-One temperature probe with an accuracy of $\pm 1^{\circ} \mathrm{C}$, and solar u.v. radiation with an Eppley radiometer which responds in the range $280-420 \mathrm{~nm}$. The data from these 3 monitors were averaged over $5 \mathrm{~min}$ intervals. The measured $\mathrm{NO}_{x}$, temperature and solar intensity data are presented in Figs 2 and 3.

Air samples for hydrocarbon analysis were collected 3 times daily (mid-morning, late afternoon and late evening) in stainless steel canisters pressurized to 35 psi by a stainless steel metal bellows pump and analysed by Gas Chromatography. The overall precision of the hydrocarbon measurements was estimated to be $30 \%$. Details of the measurements have been discussed by Bottenheim et al. (1990).

In the daytime, NHCs are destroyed quickly through reactions with hydroxyl radicals. For example, the chemical lifetime of isoprene can be as short as $30 \mathrm{~min}$, which is shorter than or comparable to the vertical diffusion time in the planetary boundary layer (PBL). NHCs are emitted into the PBL from the underlying vegetative surface. This, together with the short lifetime, leads to a rapid decrease of NHC. concentrations with height (Hov et al., 1983; Trainer et al, 1987a). This is quite different from the vertical distribution of trace gases of anthropogenic origin, transported (advected) from other regions. For the latter, a uniform concentration throughout the PBL can be reasonably assumed. Thus, it would be improper to use a single uniform box model to represent the whole PBL if one is interested in evaluating the impacts of NHCs on the photochemistry of ambient air.

In the present study, the PBL is divided into two layers. Isoprene, which is used to represent NHCs because of the dominance of deciduous trees at the Dorset site, is treated differently in the two layers. In the lower layer, isoprene was set to the measured value while the concentration in the upper layer was set to zero to reflect the rapid decrease with height. The reasons for this treatment are as follows. Firstly, because of the valley-type topography of the Dorset site, the strong turbulence which occurs in the lower part of the PBL during sunny summer days mixes isoprene fairly well up to about $150 \mathrm{~m}$. This was confirmed in a separate field study of vertical isoprene profiles conducted by Ontario Hydro at the Dorset site in August 1989 (Ontario Hydro, 1991). Isoprene concentrations were measured up to about $300 \mathrm{~m}$ at 4 levels using a tethered helium balloon technique, fashioned after that of Zimmerman et al. (1988b). Samples were collected in Teflon bags using remotely-activated pumps $(\sim 2.5 \mathrm{~min}$ to fill the bags) and then transferred to evacuated canisters and analysed as described by Bottenheim et al. (1990). For a typical strong convective case, concurrent vertical measurements of isoprene and temperature are plotted in Fig. 4, where the width of the bars represents the measurement uncertainty. It is seen that isoprene was well mixed in the lower PBL whereas its mixing ratio fell off rapidly above about $150 \mathrm{~m}$. In addition, aircraft measurements conducted in the Dorset-Egbert area during the first week of August 1988 indicated that isoprene concentrations were only $0.1 \mathrm{ppbv}$ at $420 \mathrm{~m}$ above the ground while the simultaneous ground-level concentrations were about $0.7 \mathrm{ppbv}$ (Bottenheim et al., 1990).

A shallow nocturnal inversion layer, with a depth of about $150 \mathrm{~m}$, as indicated from acoustic sounding data, separates the air aloft from the surface. Chemical species above the inversion layer do not experience depletion due to dry 


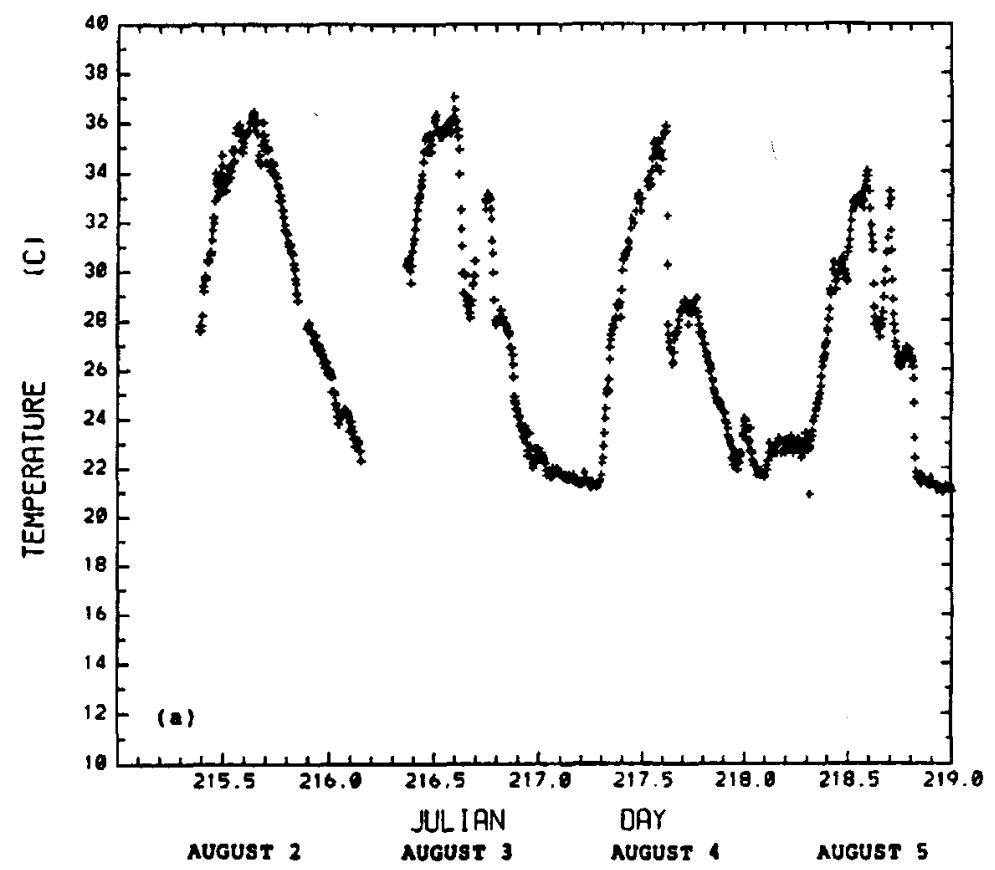

OBgEnVED sOLAR RAIATION (EPPLEx)

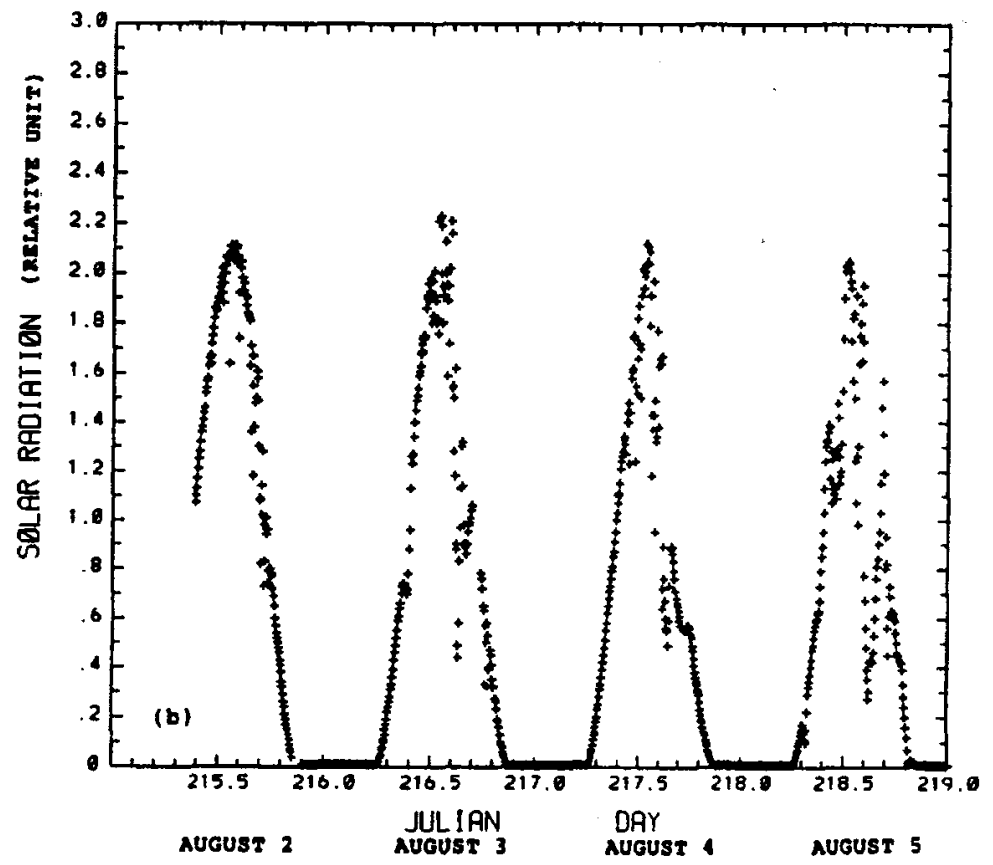

Fig. 3. (a) Measured ambient temperature at Dorset, Ontario during 2-5 August 1988.

(b) Measured solar intensity at Dorset, Ontario during 2-5 August 1988.

deposition whereas those confined to the inversion layer suffer surface losses. After sunrise, breakup of the nocturnal layer results in downward mixing of the air from above. The downward mixing is responsible for the observed increases of $O_{3}$ and other secondary pollutants in the morning hours.
During the day, the PBL develops up to about $1000 \mathrm{~m}$ above the ground (P. Chen, pers. comm., 1989) and is followed by the formation of the radiation inversion around sunset.

Based on the above considerations, an algorithm which describes the nocturnal inversion, the variation of the depth 


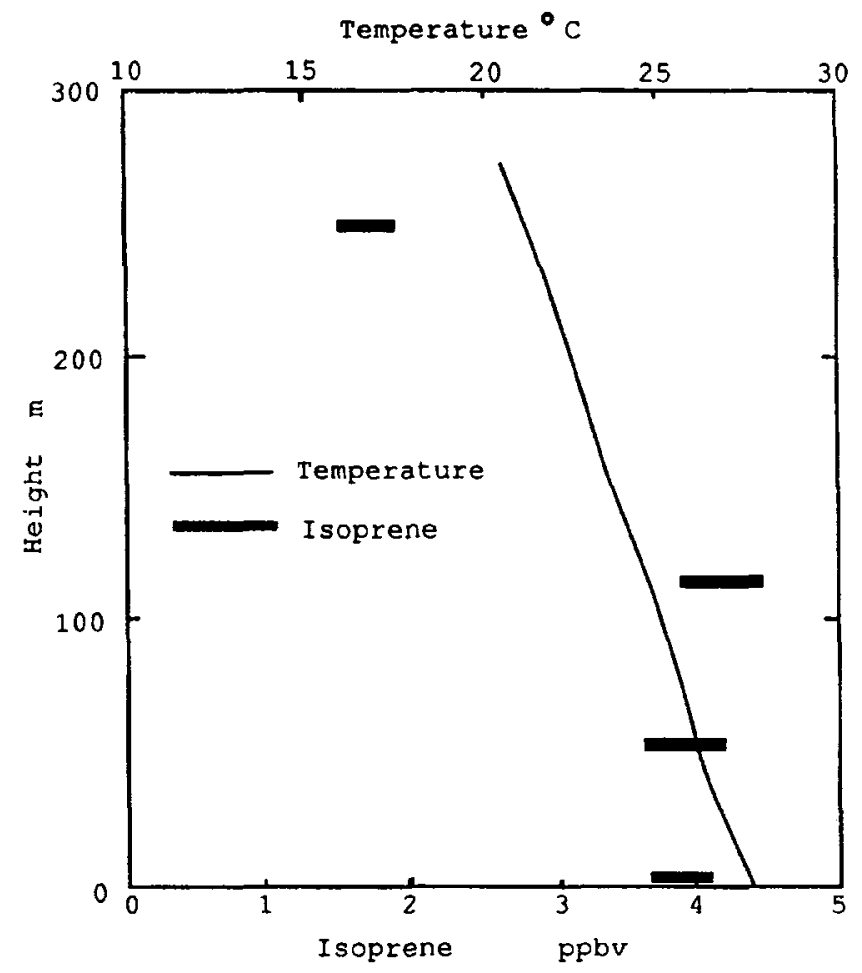

Fig. 4. Concurrent measurements of vertical profiles of isoprene and temperature at Dorset, Ontario on 1 August 1989.

of the PBL and the strong vertical gradient in isoprene concentration was designed. The diurnal variation of mixing height is presented in Fig. 5. During the night, separate boxes are applied to the nocturnal inversion layer and the air above. Calculations within the inversion layer (the lower box) include losses due to deposition to the surface while calculations for the upper box do not. In the morning, species from the two boxes are mixed as the nocturnal inversion breaks up. The mixing rate is determined by the rate of change of the mixing height. During the day, separate boxes are again imposed on the PBL, one between the surface and $150 \mathrm{~m}$, and the other from $150 \mathrm{~m}$ up to the mixing height. The contents of the two boxes are mixed every $\mathbf{4 0} \mathrm{min}$. In all cases, the isoprene concentration was set to zero above $150 \mathrm{~m}$ while the measured values were used below $150 \mathrm{~m}$ to reflect the characteristic vertical distribution of isoprene discussed above. The concentrations of AHCs were set to the same values for both boxes.

The photochemical box model used in this study has been described in detail elsewhere (Liu et al., 1987; Trainer et al., 1987a; Lin et al., 1988). Briefly, the model includes the chemistry of alkanes up to butane and the alkenes $\mathrm{C}_{2} \mathrm{H}_{4}$ and $\mathrm{C}_{3} \mathrm{H}_{6}$ using the reaction scheme proposed by Atkinson $\mathrm{et}$ al. (1982), and Atkinson and Lloyd (1984). In the present study, the levels of aromatics and higher anthropogenic alkanes and alkenes were very low compared with those of ethane, propane, n-butane, ethylene and propylene. All anthropogenic hydrocarbons with more than 3 carbon atoms were treated as $n$-butane. The reaction rate constants have been updated according to the recommendations of JPL (1990) and IUPAC (1989). The model uses isoprene as the only component of NHCs. This is justified on the basis of the predominance of deciduous trees in the local forest mix. The isoprene reaction scheme proposed by Lloyd et al. (1983) was used in the model.

\section{CALCULATIONS AND RESULTS}

The measured $\mathrm{NO}_{x}$ and NMHC concentrations were used as inputs to the model calculations. Since the hydrocarbons were measured at discrete times, linear interpolation was employed to extend the data set over the 4-day modelling period, as shown for selected hydrocarbons in Fig. 6. The measured solar u.v. flux was used to account for the effects of clouds on the photodissociation rate coefficients (Js). The photodissociation coefficients were calculated for 2-5 August at $45^{\circ} 13^{\prime} \mathrm{N}$ latitude for a clear sky condition. The absorption cross-sections and quantum yields given in JPL (1990) and the solar flux in NASA (1979) were used in the calculation. A column $\mathrm{O}_{3}$ of 313 Dobson units and a surface albedo of 0.1 were assumed. The effects of Rayleigh and Mie scattering were included following the approach of Anderson and Meier (1979). 18 August 1988 was a perfectly cloud-free day suitable for calibrating the calculated photodissociation coefficients against the Eppley radiometer. For the days of the model run, where there was significant but not heavy cloud, the calculated photodissociation coefficients were then scaled from the clear sky condition by the ratio of the measured solar u.v. flux to that measured on 18 August.

Dry deposition of the species with significant surface deposition velocities was included. In the study, a deposition velocity of $0.5 \mathrm{~cm} \mathrm{~s}^{-1}$ was used for the 


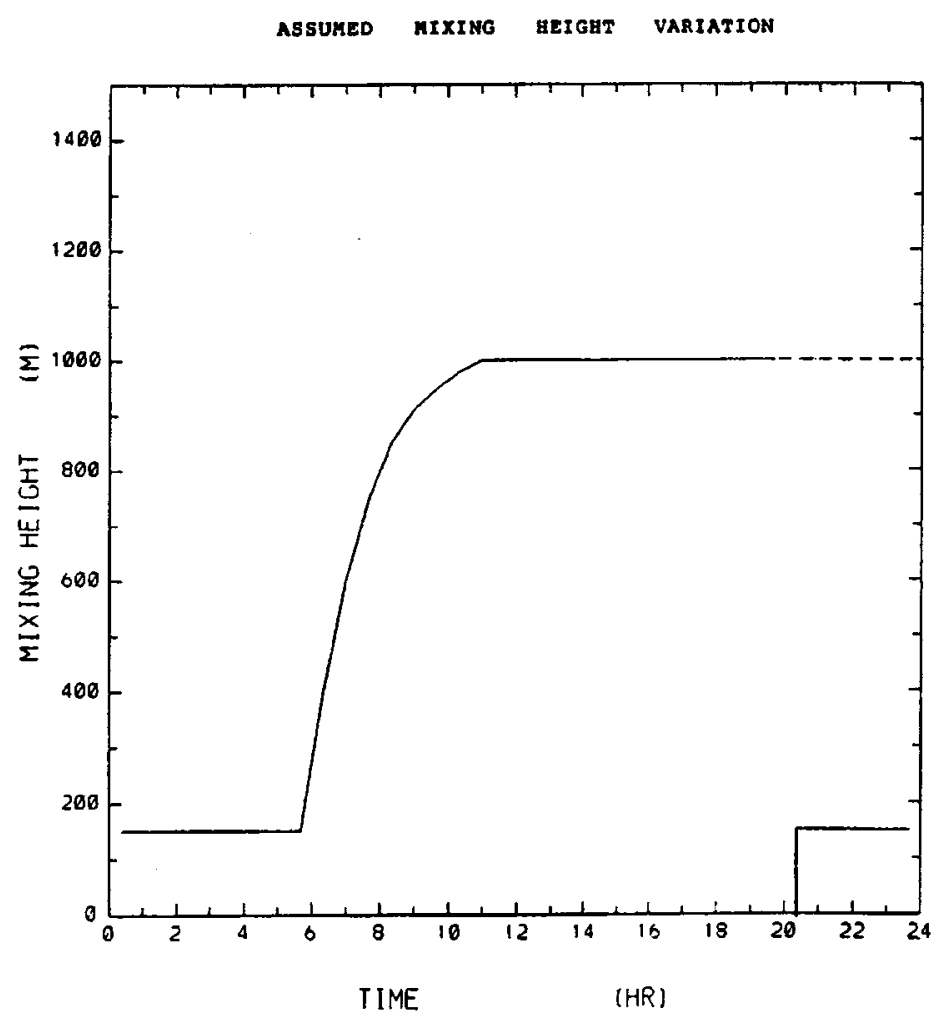

Fig. 5. Assumed diurnal variation of mixing height at Dorset, Ontario.

deposition of $\mathrm{O}_{3}$. This value is consistent with the measurements made by Lenschow et al. (1982) and Colbeck and Harrison (1985). A deposition velocity of $1 \mathrm{~cm} \mathrm{~s}^{-1}$ was adopted for $\mathrm{HNO}_{3}$ based on the measurements of Huebert and Robert (1985). Deposition velocities for several other secondary products were set as follows: $0.3 \mathrm{~cm} \mathrm{~s}^{-1}$ for PAN (Garland and Penkett, 1976; McRae and Russell, 1984); $0.5 \mathrm{~cm} \mathrm{~s}^{-1}$ for $\mathrm{H}_{2} \mathrm{O}_{2}$ and $\mathrm{CH}_{3} \mathrm{OOH}$ and $0.75 \mathrm{~cm} \mathrm{~s}^{-1}$ for aldehydes (Wesely, 1989). Background levels of $\mathrm{CO}$ and $\mathrm{CH}_{4}$ were assumed to be $200 \mathrm{ppbv}$ and $1600 \mathrm{ppbv}$, respectively.

The model was initialized with a 4-day run. The calibrated photolysis rates and the observed diurnal variations of temperature, $\mathrm{NO}_{x}$ and NMHCs of 2 August 1988 were used as inputs for the 4-day period. Steady diurnal variations of chemical species were established by the end of the 4-day period. Input variables were then set according to their actual variations from 3 to 5 August. Modelled results from the 4 th to the 7 th model day were extracted and compared with measurements of $\mathrm{O}_{3}$ and $\mathrm{CH}_{2} \mathrm{O}$ made during the $\mathrm{O}_{3}$ episode, 2-5 August 1988.

Calculated and measured $\mathrm{O}_{3}$ concentrations are plotted against time for the 4-day episode in Fig. 7. It is apparent that the model calculation reproduced the main features of the observed $\mathrm{O}_{3}$ episode. That is, the general diurnal pattern and the peak concentrations, ranging from 75 to $105 \mathrm{ppbv}$ with the highest values at the beginning of the episode, were reasonably well simulated. A similar comparison for formaldehyde is presented in Fig. 8. It is seen that on average the model slightly underpredicted formaldehyde concentrations. During the first 2 days, differences between the predicted and the observed daily maxima are as high as $50 \%$, although there is considerable scatter in the data. In general, the results from the current model calculation show reasonable agreement with the observed $\mathrm{O}_{3}$ and formaldehyde variations for this episode.

The sensitivity of the $\mathrm{O}_{3}$ and formaldehyde levels to the uncertainties in the measured $\mathrm{NO}_{x}$ and hydrocarbon concentrations were tested by changing these values in the model calculations. When a $20 \%$ change (the upper limit of the uncertainty) was applied to $\mathrm{NO}_{x}$, the daily maxima of $\mathrm{O}_{3}$ and formaldehyde changed by less than $10 \%$. When a $30 \%$ uncertainty was assumed for hydrocarbon measurements, a change in concentration of this magnitude resulted in about the same percentage changes of the daily maxima of $\mathrm{O}_{3}$ and formaldehyde. This was consistent with the fact that the $\mathrm{O}_{3}$ production was hydrocarbon limited during the episode as we will discuss in the following section.

\section{DISCUSSION}

\section{Variation of total hydrocarbon reactivity}

Both the observed and model-predicted $\mathrm{O}_{3}$ variations during the 4-day episode show a clear descend- 

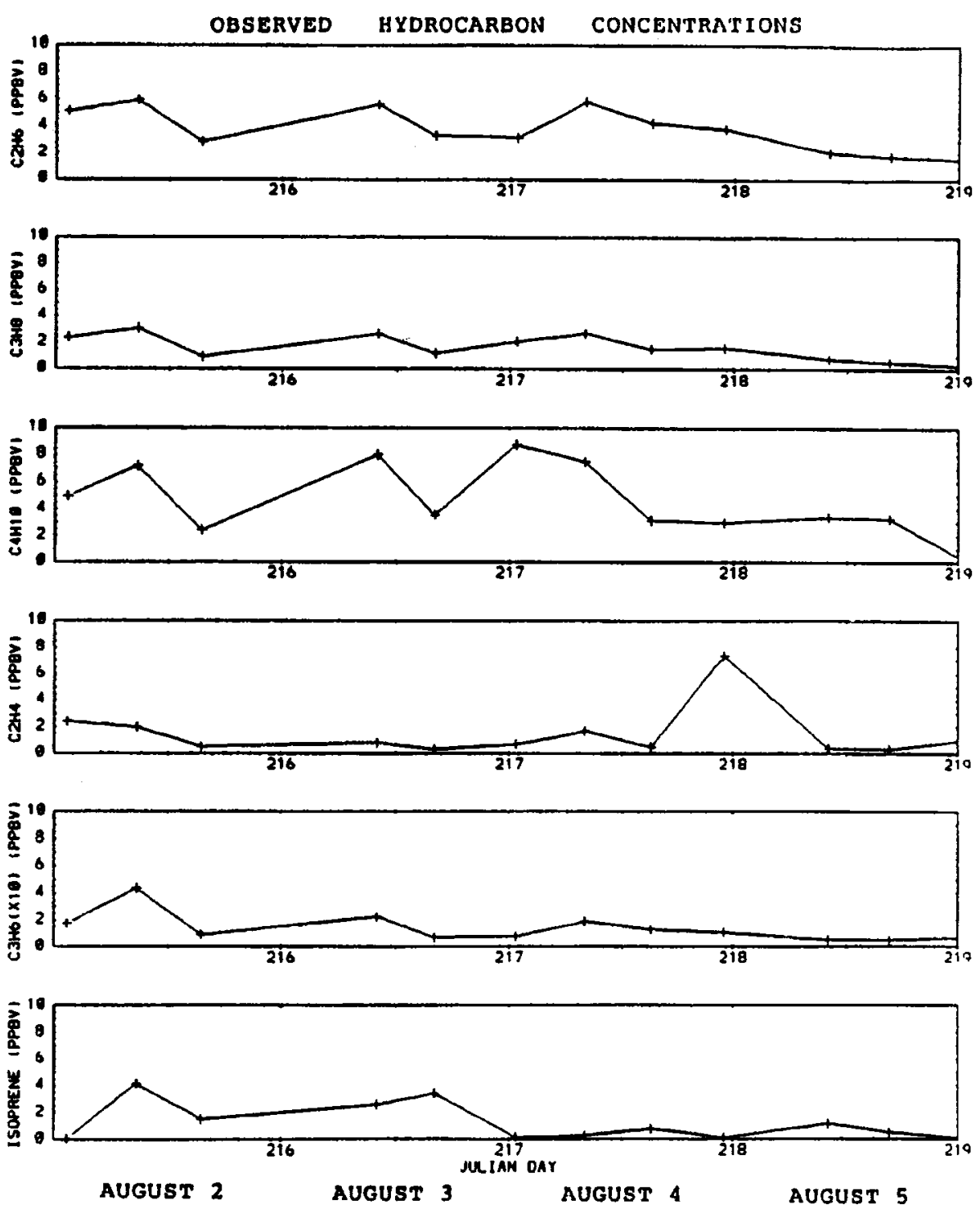

Fig. 6. Linearly interpolated hydrocarbon concentrations used as inputs to model calculations. Cross marks indicate the measurements.

ing trend of the $\mathrm{O}_{3}$ daily maximum. This can be explained from the levels of $\mathrm{O}_{3}$ precursors. Since $\mathrm{NO}_{x}$ fluctuated around the $5 \mathrm{ppbv}$ level during the 4 days, $\mathrm{O}_{3}$ variations were mainly controlled by the levels of hydrocarbons as will be discussed below. To illustrate the variation of the $\mathrm{O}_{3}$ production potential of the hydrocarbons (Uno et al., 1985), the reactivity of the hydrocarbon mixture was calculated for the 4 days. The reactivity of the hydrocarbon mixture was defined as

$$
\sum_{i} k_{\mathrm{OH}, i} \cdot C_{i}
$$

where $k_{\mathrm{OH}, i}$ denotes the reaction rate coefficient of the $i$ th hydrocarbon with $\mathrm{OH}$ and $C_{i}$ represents the concentration of the ith hydrocarbon in carbon units. Both measured AHCs and isoprene were included in the calculation. All the AHCs with carbon number greater than 3 were treated as $n$-butane in the reactivity calculation to be consistent with the model calculations mentioned earlier. The variation of hydrocarbon reactivity during the 4 days is plotted in Fig. 9 . The plot reveals a substantial decrease in the reactivity from the first day to the third day of the episode followed by a small increase on the fourth day due mainly to the increase of $\mathrm{C}_{2} \mathrm{H}_{4}$. This increase in $\mathrm{C}_{2} \mathrm{H}_{4}$ has a significant impact on formaldehyde concentrations as shown in Fig. 8. Since the upper part of the PBL serves as a large reservoir for the secondary pollutants, the longer lifetime of $\mathrm{O}_{3}$ in the upper layer 


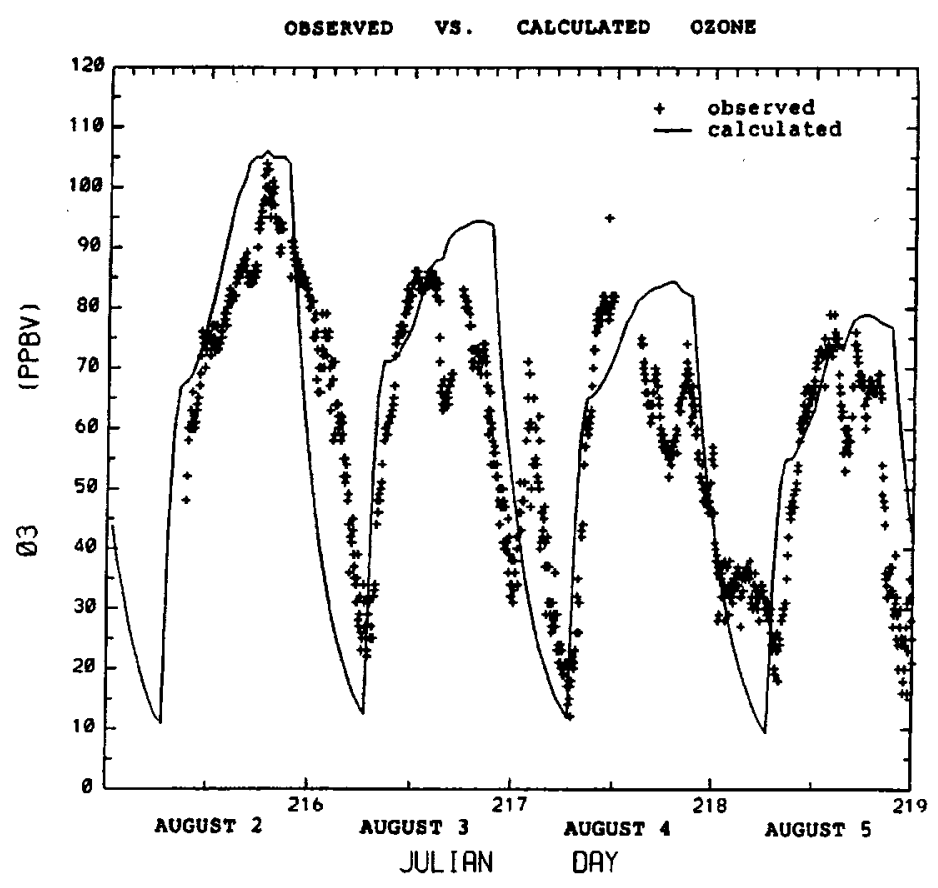

Fig. 7. Calculated $\mathrm{O}_{3}$ variation vs measured $\mathrm{O}_{3}$ variation at Dorset, Ontario from 2 to 5 August 1988.

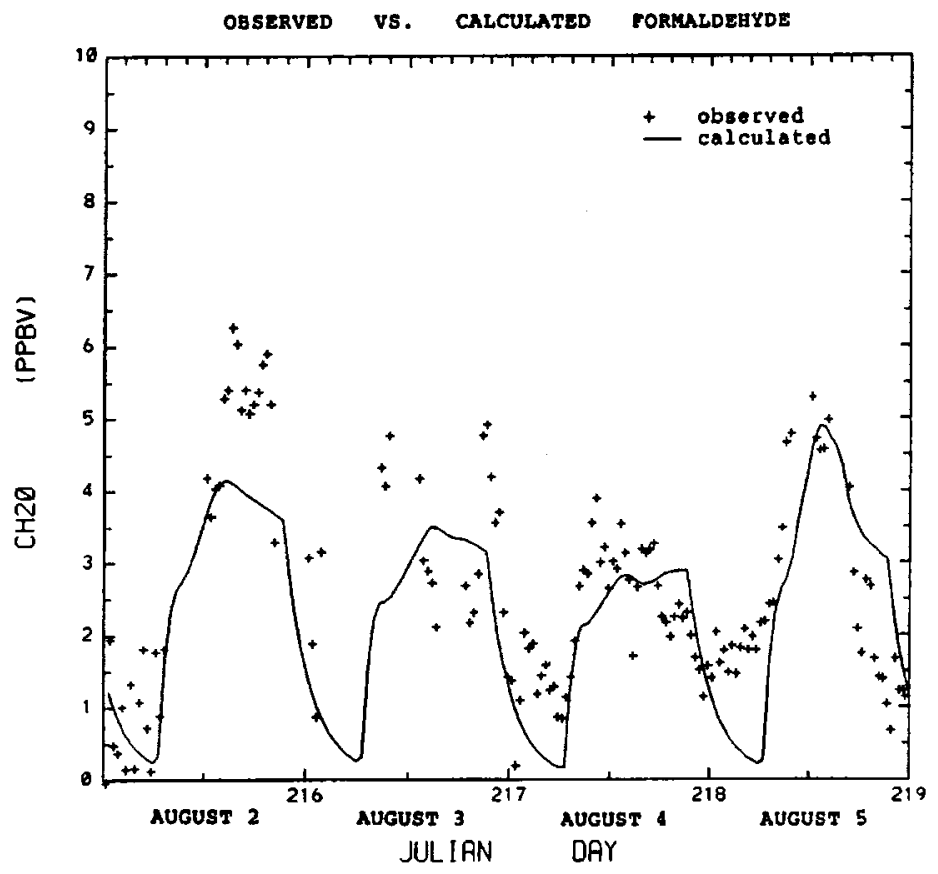

Fig. 8. Calculated $\mathrm{CH}_{2} \mathrm{O}$ variation vs measured $\mathrm{CH}_{2} \mathrm{O}$ variation at Dorset, Ontario from 2 to 5 August 1988.

of the PBL resulted in a relatively gradual decrease of daily maximum $\mathrm{O}_{3}$ over the 4-day period.

To investigate the relative importance of NHCs vs AHCs in local $\mathrm{O}_{3}$ production at the Dorset site during the $\mathrm{O}_{3}$ episode, calculations were conducted for two scenarios. In the first scenario, the parameter values discussed above were used except that the AHC concentrations were set to zero, whereas only the 
vaRIATION OF TOTAL GYDROCARBON nEACTIVITY

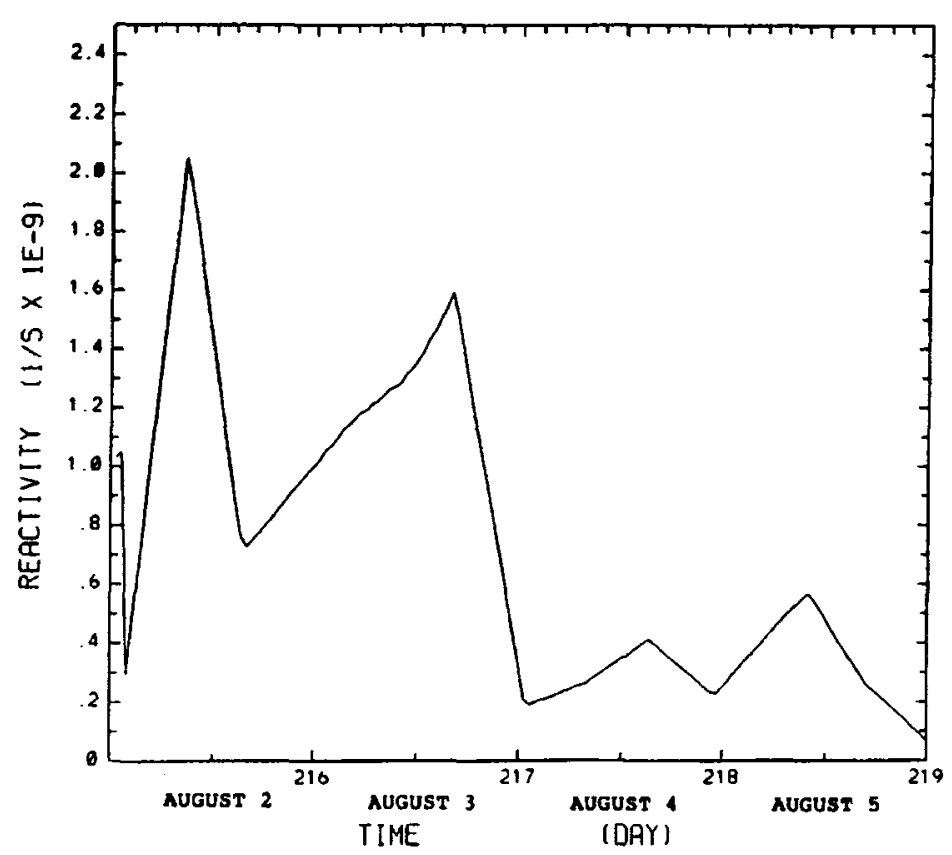

Fig. 9. Variation of the reactivity of the hydrocarbon mixture at Dorset, Ontario for the period of 2-5 August 1988.

(A)BASELINE RESULT (B)AN. VOC EXCLUOED

(C) ISOPRENE EXCLUDED (DICD AND CHA OXIDATION BNLY

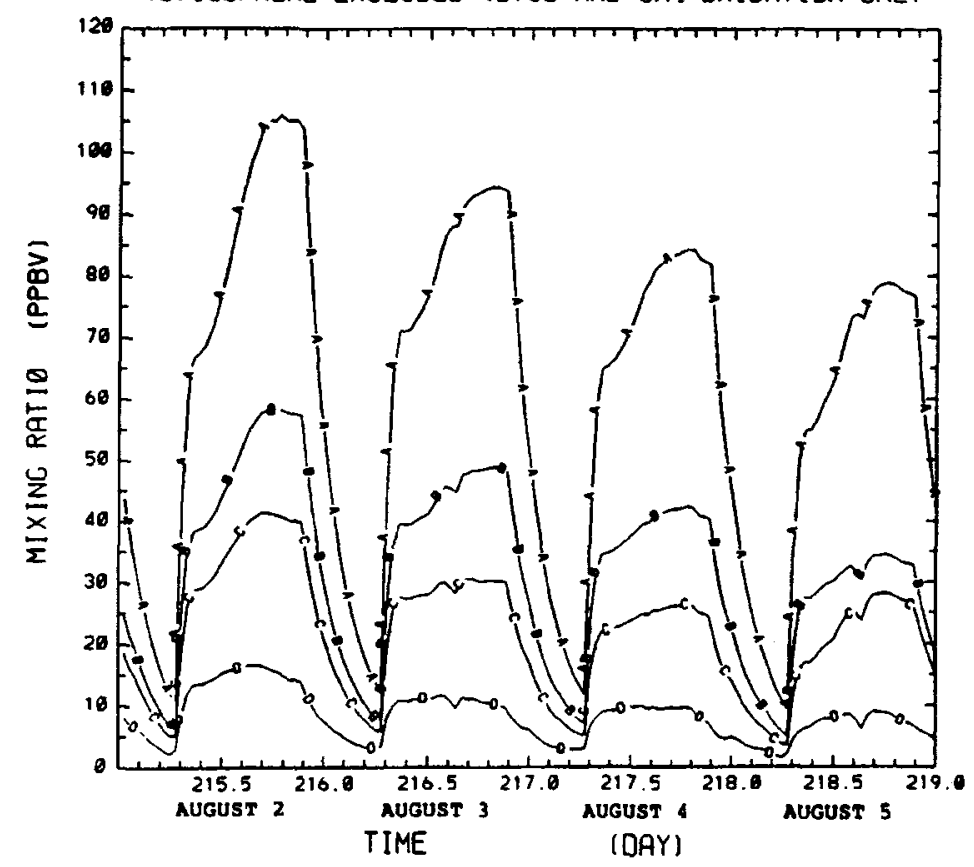

Fig. 10. Relative importance of isoprene, $\mathrm{AHCs}$ and $\mathrm{CO}+\mathrm{CH}_{4}$ in total $\mathrm{O}_{3}$ production during the modelled episode.

concentration of isoprene was set to zero in the second scenario. The calculated $\mathrm{O}_{3}$ variation from these two scenarios, together with the results from the baseline run and a run for only $\mathrm{CO}$ and $\mathrm{CH}_{4}$ chemistry, are presented in Fig. 10. From the results, one can observe the following. First, $\mathrm{CO}$ and $\mathrm{CH}_{4}$ chemistry contributed an insignificant part to local $\mathrm{O}_{3}$ production. Secondly, isoprene played a more important role in 
local $\mathrm{O}_{3}$ production than $\mathrm{AHCs}$ during the episode studied. Finally, contributions to the $\mathrm{O}_{3}$ production from these two types of hydrocarbons were not additive, simply due to the non-linearity of the photochemical system. Neither the isoprene nor the AHCs contributed more than $55 \%$ to the total $\mathrm{O}_{3}$ production during the episode.

\section{Isoprene contribution to local $\mathrm{O}_{3}$ production}

The importance of isoprene in local $\mathrm{O}_{3}$ production can be examined in a variety of ways. Here, AHC inputs will be treated as perturbations superimposed on the natural background. An isoprene contribution to local $\mathrm{O}_{3}$ production will be defined by dividing the $\mathrm{O}_{3}$ concentrations calculated in the absence of $\mathrm{AHCs}$ by those with AHCs and isoprene present. The results of the calculation thus indicate the extent to which $\mathrm{O}_{3}$ production is due to isoprene chemistry under the conditions of the model runs. The model can then be run over wide ranges of both AHC and isoprene levels. For these calculations, the mix of AHCs was set as the average one measured in the 4-day episode and the total concentration was varied; temperature and solar intensity varied according to their mean diurnal variations for the 4-day period. $\mathrm{O}_{3}$ concentrations at 6 PM, when the $\mathrm{O}_{3}$ concentration is close to its daily maximum value, were obtained and were then used to derive the isoprene contributions as defined above. In Figs 11a and 11b, the calculated isoprene contributions, in units of percentage, are presented as isopleth lines as a function of isoprene and AHCs for $\mathrm{NO}_{x}$ levels fixed at $1 \mathrm{ppbv}$ and $5 \mathrm{ppbv}$, respectively. It is apparent that, for $\mathrm{NO}_{x}$ at $1 \mathrm{ppbv}$, the isoprene contribution increases with increasing isoprene and with decreasing AHCs, as expected. For $\mathrm{NO}_{x}$ at $5 \mathrm{ppbv}$, the isoprene contribution is virtually independent of the level of isoprene as the reactivity of the mixture of $\mathrm{AHCs}$ and isoprene, defined previously, is low. When the hydrocarbon reactivity is above a certain level, the isoprene contribution increases with isoprene concentration. The hydrocarbon reactivity level separating two regions associated with different behaviours of the isoprene contribution, can be visualized as a zone running from high NHC and low AHC to low NHC and high $\mathrm{AHC}$ in Fig. 11b. In addition, comparison between Figs $11 \mathrm{a}$ and $11 \mathrm{~b}$ indicates an overall increase in the isoprene contribution as $\mathrm{NO}_{x}$ drops from 5 ppbv to 1 ppbv.

Variations of the calculated isoprene contribution to $\mathrm{O}_{3}$ production can be explained through an analysis of the chemical system. It is well known that $\mathrm{O}_{3}$ formation responds to levels of hydrocarbons in a non-linear way (e.g. Lurmann et al., 1984). The nonlinearity of the $\mathrm{O}_{3}$ production depends strongly on the amount of $\mathrm{NO}_{x}$ available (Dimitriades and Dodge, 1983). When the $\mathrm{NO}_{x}$ level is low, $\mathrm{O}_{3}$ formation is limited by the available $\mathrm{NO}_{x}$. Thus, a relatively large increase in the reactivity of hydrocarbons (e.g. adding AHCs to isoprene in this case) results in a small increase in $\mathrm{O}_{3}$. The fractional increase in $\mathrm{O}_{3}$, which is due to the addition of AHCs to the reference isoprene, becomes smaller as the level of isoprene increases. By recalling the definition of the isoprene contribution (the ratio of the $\mathrm{O}_{3}$ level produced from isoprene chemistry alone divided by the $\mathrm{O}_{3}$ level associated with isoprene plus $\mathrm{AHCs}$ ), it can be concluded that an increase in isoprene concentration results in an increase in isoprene contribution. As the $\mathrm{NO}_{x}$ level is elevated, say to 3-6 ppbv, $\mathrm{O}_{3}$ production becomes hydrocarbon limited. Now, a relatively small fractional increase in the reactivity of hydrocarbons leads to a large fractional change in $\mathrm{O}_{3}$. It implies that the isoprene contribution appears to be almost independent of the level of isoprene. However, as the ratio of hydrocarbons to $\mathrm{NO}_{x}$ increases and $\mathrm{NO}_{x}$ becomes the rate limiting factor, the isoprene contribution increases again with isoprene concentration as shown in Fig. 11b.

The dependence of the isoprene contribution to $\mathrm{O}_{3}$ production on the $\mathrm{NO}_{x}$ concentration is illustrated in Fig. 12a. In this figure the calculated $\mathrm{O}_{3}$ concentration at $1800 \mathrm{~h}$ is plotted against $\mathrm{NO}_{x}$ concentration ranging between 0.1 and $25 \mathrm{ppbv}$. For each calculation, the $\mathrm{NO}_{x}$ level was kept constant. The calculations were conducted for an average hydrocarbon mixture and average diurnal variations of temperature and solar intensity for the 4-day episode. Ten ppbC of isoprene and $35 \mathrm{ppbC}$ of $\mathrm{AHCs}$ (representative concentrations for the 4-day period) were assumed in the calculations. The two solid curves represent a normal run and a run without AHCs, while the dashed curve represents the isoprene contribution to $\mathrm{O}_{3}$ production, i.e. the ratio of the values of curve $B$ to those of curve $A$. The results indicate that, for $\mathrm{NO}_{x}$ levels below $1 \mathrm{ppbv}$, isoprene could be responsible for more than $85 \%$ of the $\mathrm{O}_{3}$ production. When $\mathrm{NO}_{x}$ increases, the contribution of isoprene to $\mathrm{O}_{3}$ production decreases. However, as $\mathrm{NO}_{x}$ increases beyond $10 \mathrm{ppbv}$, the contribution of isoprene starts to increase with increasing $\mathrm{NO}_{x}$. It is seen that there exists a maximum $\mathrm{O}_{3}$ concentration (at $1800 \mathrm{~h}$ ) for a $\mathrm{NO}_{x}$ level somewhere between 2 and 4 ppbv, and that the $\mathrm{NO}_{x}$ level associated with the maximum $\mathrm{O}_{3}$ shifts towards higher values as the hydrocarbon mixture changes from one without AHCs to one with AHCs. The $\mathrm{NO}_{x}$ level associated with the maximum $\mathrm{O}_{3}$ for a mixture of $\mathrm{AHCs}$ and isoprene will be referred to as the critical $\mathrm{NO}_{x}$ level. By recalling the definition of the isoprene contribution, the above implies that a minimum value of the isoprene contribution occurs at a $\mathrm{NO}_{x}$ level that is located slightly on the high side of the critical $\mathrm{NO}_{x}$ level (at $\sim 6 \mathrm{ppbv}$ ) as shown by the dashed curve. This is within the typical range of $\mathrm{NO}_{x}$ concentration (3-6 ppbv) of the episode. Under these conditions AHCs have a relatively large impact on local $\mathrm{O}_{3}$ production.

For the case of the $\mathrm{O}_{3}$ episode studied, the average $\mathrm{NO}_{x}$ mixing ratio was about 5 ppbv. The levels of isoprene were at or below about 10 ppbC. Applying 

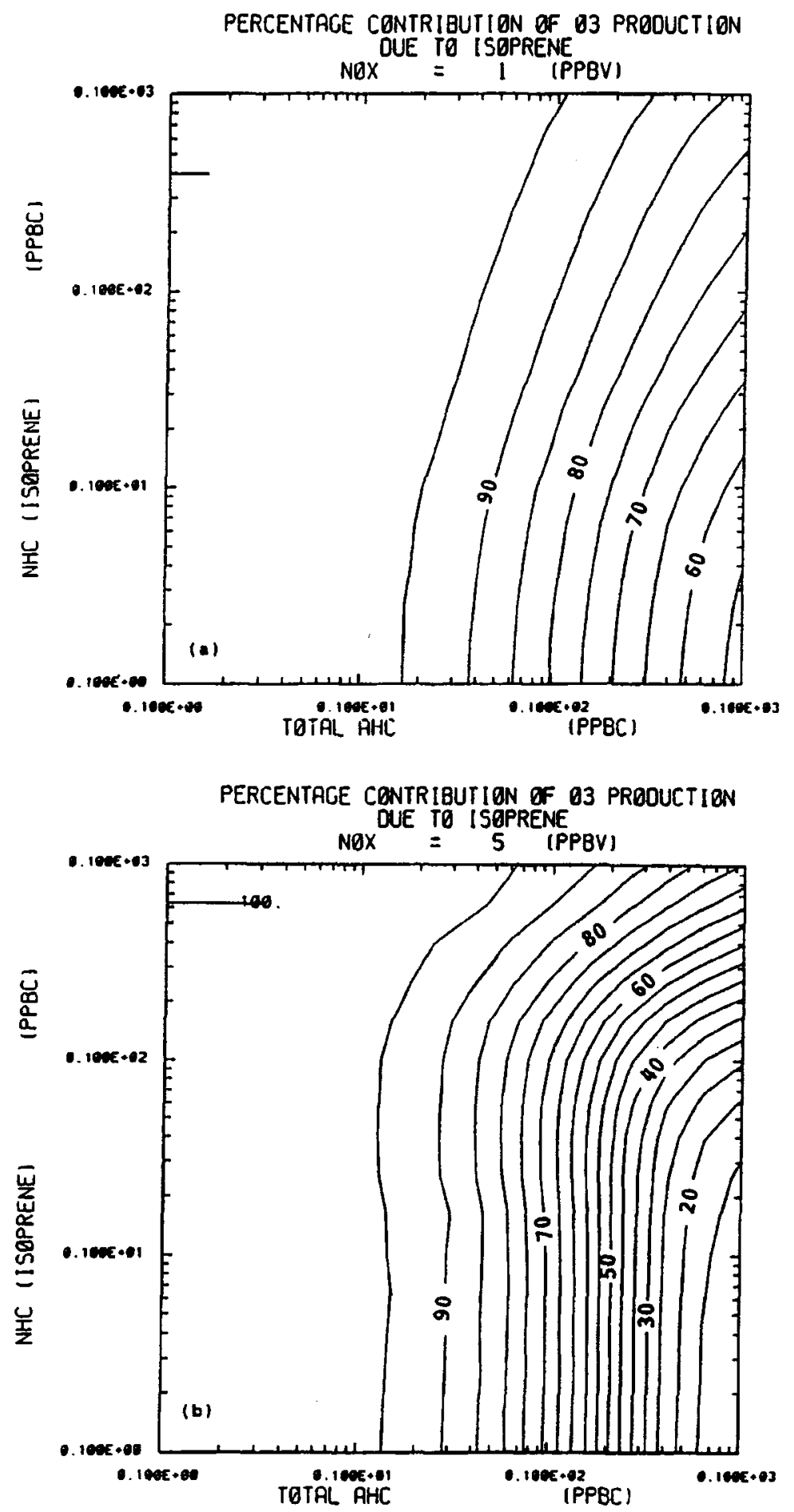

Fig. 11. (a) Calculated isoprene contributions to $\mathrm{O}_{3}$ production, in unit of $\%$, for $\mathrm{NO}_{x}$ at 1 ppbv. (b) Same as (a), but for $\mathrm{NO}_{x}$ at 5 ppbv.

5 ppbv of $\mathrm{NO}_{x}$ in Fig. 12a, one finds that the isoprene contribution could have been $49 \%$. This number is consistent with the results of the sensitivity tests shown in Fig. 10.

\section{Comparison with other studies}

It is instructive to compare the above results with similar calculations based on data obtained at other rural sites. The levels of isoprene during the episode 

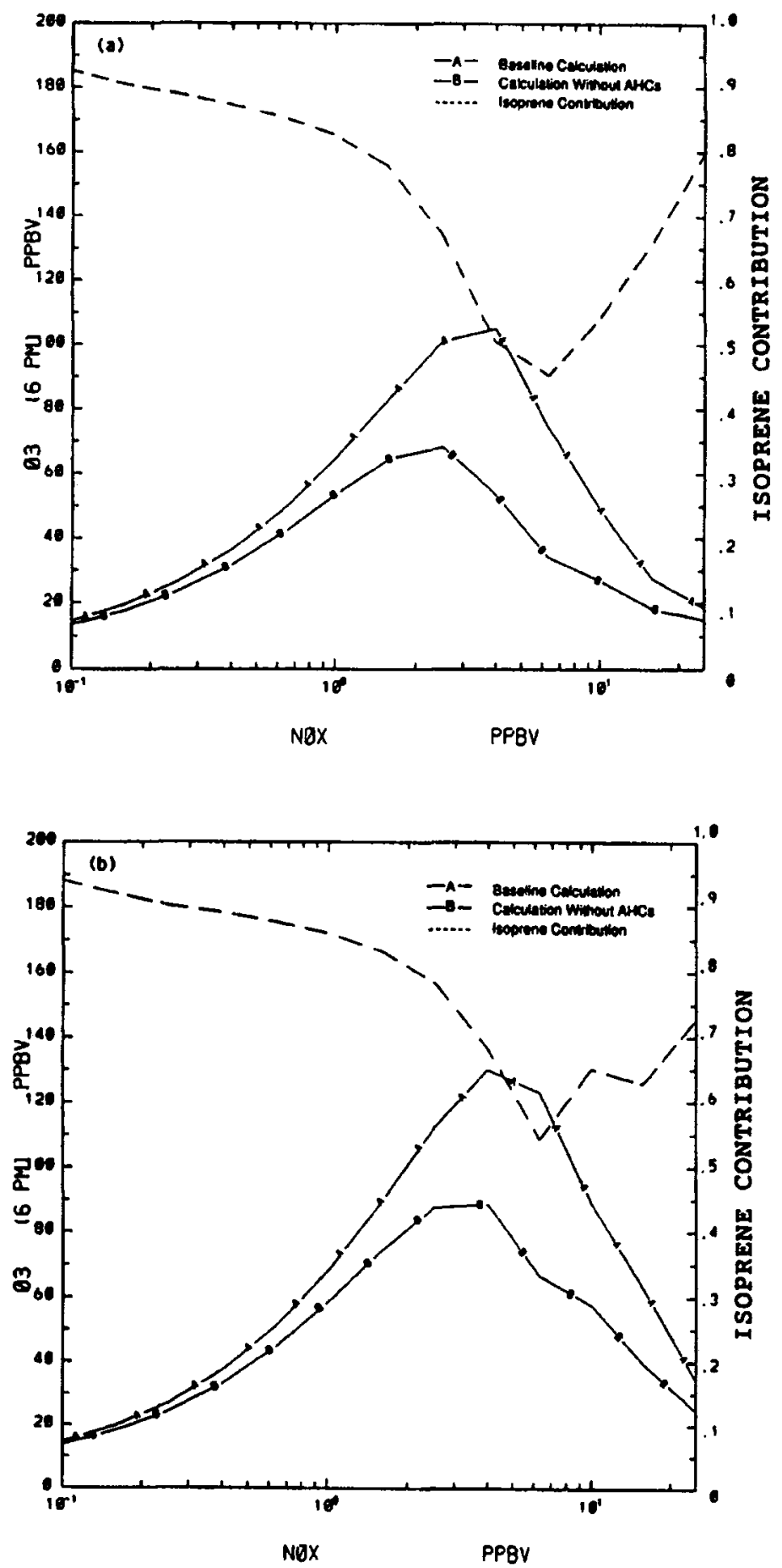

Fig. 12. (a) Calculated non-linear response of $\mathrm{O}_{3}$ to hydrocarbons and $\mathrm{NO}_{x}$ for $A$ HCs at $35 \mathrm{ppbC}$ and isoprene at $10 \mathrm{ppbC}$. Curves $A$ and $B$ represent a normal run and a run without AHCs, respectively. The dashed curve represents isoprene contributions to $\mathrm{O}_{3}$ production. (b) Same as (a), but for isoprene at 20 ppbC.

were not as high as those observed at more southerly rural sites (Trainer et al., 1987b, 1991; Yokouchi and Ambe, 1988; Niki et al., 1991) or even those measured on other occasions at the same site. On the other hand, the levels of $\mathrm{NO}_{x}$ during the episode were fairly high. The typical range of $\mathrm{NO}_{x}$ concentrations was 3-6 ppbv for the 4-day period. Median afternoon concentrations of $\mathrm{NO}_{x}$ measured at Scotia, PA, a rural 
site in the eastern U.S., were about $0.6 \mathrm{ppbv}$ (Hubler $\boldsymbol{e t}$ al., 1987). Even for an $\mathrm{O}_{3}$ episode under stagnant meteorological conditions, $\mathbf{N O}_{x}$ at Scotia varied around the 2 ppbv level (Trainer et al., 1987b, 1991). During that episode, the concentrations of isoprene were about $20 \mathrm{ppbC}$. To enable comparison of our results from Dorset with those from Scotia, the calculations that yielded Fig. 12a, were repeated with an isoprene level of $20 \mathrm{ppbC}$. Results from the calculations are plotted in Fig. $12 \mathrm{~b}$ and show similar characteristics to the ones in Fig. 12a, e.g. the $\mathrm{O}_{3}$ maxima appear around $\mathrm{NO}_{x}$ concentrations of 2-4 ppbv. The relative importance of isoprene vs AHCs, however, becomes greater since more isoprene is available. For a $\mathrm{NO}_{x}$ level of $5 \mathrm{ppbv}$, the isoprene contribution accounts for $62 \%$ of the total $\mathrm{O}_{3}$. If the $\mathrm{NO}_{x}$ level drops to $2 \mathrm{ppbv}$, the isoprene contribution is further enhanced to $81 \%$. This is similar to the findings of Trainer et al. (1987b) in a case study for the Scotia, PA site.

There were limitations in the present modelling study. We were using measured $\mathrm{NO}_{x}$ and hydrocarbon levels as inputs into the calculations instead of adjusting fluxes to match the measured levels of the precursors. Our choice was based on the consideration that a flux treatment would introduce more uncertainties into the calculated results within the current box model framework. Thus, the present treatment prohibited us from rigorously testing the sensitivity of $\mathrm{O}_{3}$ formation to changes in emissions of precursors. In our calculations, the vertical dilution effect was represented, to some extent, by using multiple boxes. However, no effect of long-range transport was explicitly included. The Dorset site is downwind of the anthropogenic source regions in the midwestern U.S. and southern Ontario under the condition of a southwesterly flow. Since the transport time of an air parcel from the source area to the rural site is of the order of a day, there should be a significant amount of secondary oxidants accumulated in the air mass. Thus, these species might be somewhat underpredicted by the model.

\section{CONCLUSIONS}

In the present paper, an $\mathrm{O}_{3}$ episode under stagnant meteorological conditions at the Dorset site in central Ontario during 2-5 August 1988 was simulated with a photochemical box model with a two-layer treatment utilizing observed concentrations of $\mathrm{NO}_{x}$ and hydrocarbons. The calculated results from model runs showed satisfactory agreement with the observed $\mathrm{O}_{3}$ and formaldehyde data. The sensitivity runs with either AHCs or isoprene absent indicated that isoprene played an important role relative to AHCs in the local $\mathrm{O}_{3}$ production during this event.

The isoprene contribution to the local $\mathrm{O}_{3}$ production was defined by dividing the $\mathrm{O}_{3}$ amount formed in the absence of AHCs by the one in the presence of
AHCs. Model calculations indicated that the isoprene contribution is characterized by a strong $\mathrm{NO}_{x}$ dependence. A minimum value of the contribution occurs usually at a $\mathrm{NO}_{x}$ level of $\sim 6$ ppbv. The $\mathrm{NO}_{x}$ dependence can be explained by the non-linearity of the photochemical system. Around the $\mathrm{NO}_{x}$ level associated with the minimum value of the isoprene contribution, AHCs have a relatively large impact on $\mathrm{O}_{3}$ formation while, beyond this region, the level of $\mathrm{NO}_{x}$ gradually becomes the limiting factor in $\mathrm{O}_{3}$ production. However, it is worth noting that $\mathrm{O}_{3}$ levels are usually low when $\mathrm{NO}_{x}$ levels are either very low or very high. For the episode studied here, the representative range of $\mathrm{NO}_{x}$ levels was about 3-6 ppbv. Therefore, the $\mathrm{O}_{3}$ production was significantly influenced by the presence of AHCs.

The present study was performed under the conditions of a specific $\mathrm{O}_{3}$ episode. It should be noted that the episode was characterized by relatively high $\mathrm{NO}_{x}$ and relatively low isoprene levels compared to measurements made by others (e.g. Trainer et al., 1987b, 1991). As more data for central Ontario become available, further work is planned to improve our understanding of the role played by NHCs in the $\mathrm{O}_{3}$ budget of the region.

Acknowledgements-The authors would like to thank R. Berman for data acquisition and analysis, and to acknowledge the contributions of K. Puckett, C. Francis, J. Jones, J. P. Varto, C. Blair, D. Morris, S. Malle, B. Zhang, H. Malle, L. Toth and B. Kieser for their assistance in all areas of operation. D. R. Hastie acknowledges support from the Ontario Ministry of the Environment. H. Niki and P. B. Shepson acknowledge support from the Atmospheric Environment Service. This is a CIRAC contribution, \#90-3.

\section{REFERENCES}

Altshuller A. P. (1983) Review: natural volatile organic substances and their effect on air quality in the United States. Atmospheric Environment 17, 2131-2165.

Anderson D. E. and Meier R. R. (1979) Effects of anisotropic multiple scattering on solar radiation in the troposphere and stratosphere. Appl. Opt. 18, 1955-1960.

Atkinson R. and Lloyd A. C. (1984) Evaluation of kinetic and mechanistic data for modelling of photochemical smog. $J$ phys. Chem. Ref. Data 13, 315-444.

Atkinson R., Lloyd A. C. and Winges L. (1982) An updated chemical mechanism for hydrocarbon $/ \mathrm{NO}_{x} / \mathrm{SO}_{2}$ photooxidations suitable for inclusion in atmospheric simulation models. Atmospheric Environment 16, 1341-1355.

Bottenheim J. W., Brice K. A., Wang D., Handy B., Singer E. and Niki H. (1990) Measurements of light molecular weight hydrocarbons at Egbert, Dorset and aloft (DC-3 and Twin Otter) during EMEFS-summer 1988: method and results. Report ARD-90-004, Atmospheric Research Division, Atmospheric Environment Service, Downsview, Ontario, Canada.

Chameides W. L., Lindsay R. W., Richardson J. and Kiang C. S. (1988) The role of biogenic hydrocarbons in urban photochemical smog: Atlanta as a case study. Science 241 , 1473-1475.

Chang J. S., Brost R. A., Isaksen I. S. A., Madronich S. Middleton P., Stockwell W. R. and Walcek C. J. (1987) A three-dimensional Eulerian acid deposition model: 
physical concepts and formulation. J. geophys. Res. 92, $14,681-14,700$

Colbeck I. and Harrison R. M. (1985) Dry deposition of ozone: some measurements of deposition velocity and of vertical profiles to 100 meters. Atmospheric Environment 19. 1807-1818.

Dimitriades B. and Dodge M. (1983) (editors) Procedings of the empirical kinetic modeling approach (EKMA) validation workshop, EPA Report No. EPA-600/9-83-014.

Garland J. and Penkett S. A. (1976) Absorption of peroxyacetylnitrate and ozone by natural surfaces. Atmospheric Environment 10, 1127-1131.

Harris G. W., Mackay G. I., Iguchi T., Mayne L. K. and Schiff H. I. (1989) Measurements of formaldehyde in the troposphere by Tunable Diode Laser Absorption Spectroscopy. J. atmos. Chem. 8, 119-137.

Hov O., Schjoldager J, and Wathne B. M. (1983) Measurement and modelling of the concentrations of terpenes in coniferous forest air. J. geophys. Res. 88, 10,679-10,688.

Hubler G. et al. (1987) Partitioning of reactive odd nitrogen species in the tropospheric boundary layer. Paper presented at the 6th Int. Symp. Commission on Atmospheric Chemistry and Global Pollution. Int. Ass. of Met. and Atmos. Phys., Peterborough, Ontario, Canada, 23-29 August.

Huebert B. J. and Robert C. H. (1985) The dry deposition of nitric acid to grass. J. geophys. Res. 90, 2085-2090.

IUPAC (1989) Evaluated photochemical data for atmospheric chemistry: supplement III. J. phys. Chem. Ref. Data 89, 881-1097.

JPL (1990) Jet Propulsion Laboratory, Chemical kinetics and photochemical data for use in stratospheric modelling. Evaluation Number 9. Calif. Inst. of Technol., Pasadena.

Lamb B., Guenther A., Gay D. and Westberg H. (1987) A national inventory of biogenic hydrocarbon emissions. Atmospheric Environment 21, 1695-1705.

Lenschow D. H., Pearson R., Jr and Stankor B. B. (1982) Measurements of ozone vertical flux to ocean and forest. J. geophys. Res. 87, 8833-8837.

Logan J. (1989) Ozone in rural areas of the United States. $J$. geophys. Res. 94, 8511-8532.

Lin X., Trainer M. and Liu S.C. (1988) On the nonlinearity of the tropospheric ozone production. $J$, geophys. Res. 93, $15,879-15,888$.

Liu S. C., Trainer M., Fehsenfeld F. C., Parrish D. D., Williams E. J., Fahey D. W., Hubler G. and Murphy P. C. (1987) Ozone production in the rural troposphere and the implications for regional and global ozone distributions. $J$. geophys. Res. 92, 4191-4207.

Lloyd A. C., Atkinson R., Lurmann F. W. and Nitta B. (1983) Modelling potential ozone impacts from natural hydrocarbons-1. Development and testing of a chemical mechanism for the $\mathrm{NO}_{x}$-air photooxidations of isoprene and $\alpha$-pinene under ambient conditions. Atmospheric Environment 17, 1931-1950.

Lurmann F. W., Lloyd A. C. and Nitta B. (1983) Modelling potential ozone impacts from natural hydrocarbons-II. Hypothetical biogenic HC emission scenario modelling. Atmospheric Environment 17, 1951-1963.

Lurmann F. W., Nitta B., Ganesan K. and Lloyd A. C. (1984) Modelling potential ozone impacts from natural sourcesIII. Ozone modelling in Tampa/St. Petersburg, Florida. Atmospheric Environment 18, 1133-1143.

McRae G. J. and Russell A. G. (1984) Dry deposition of nitrogen-containing species. In Deposition Both Wet and Dry (edited by Hicks B. B.), chapter 9, pp. 153-193. Acid
Precipitation Series. (series edited by Teasley J. I.). Butterworth, Boston.

Modelling Workgroup (1990) Modelling Workgroup Final Report. Prepared for the Federal/Provincial Long Range Transport of Air Pollutants (LRTAP) Steering Committee and Canadian Council of Ministers of the Environment (CCME).

NASA (1979) The stratosphere: present and future. Ref. Publ. 1049.

Niki H. et al. (1991) A comparison of speciated non-methane hydrocarbon concentrations at four rural sites in eastern North America (in preparation.)

OME (1984) Ontario Ministry of the Environment, 1980 Ontario VOC emission inventory: Summary Report. ARB-183-85-AQM, November.

OME (1990) Ontario Ministry of the Environment, Air quality in Ontario 1988. ISSN-0840-9366.

Ontario Hydro (1991) Vertical profiles of VOCs at Dorset, Ontario. Research Division Report (in preparation.)

Puckett K. J. et al. (1991) Some results from the Spring and Summer Intensive Measurement Periods of the Eulerian Model Evaluation Field Study (EMEFS) (in preparation.)

Shepson P. B, Hastic D. R., Schiff H. I., Polizzi M., Bottenheim J. W., Anlauf K. G., Mackay G. I. and Karecki D. R. (1991) Atmospheric concentrations and temporal variations of $\mathrm{C}_{1}-\mathrm{C}_{3}$ carbonyl compounds at two rural sites in central Ontario. Atmospheric Environment 25A, 20012015.

Trainer M., Hsie E. Y., Mckeen S. A., Tallamraju R., Parrish D. D., Fehsenfeld F. C. and Liu S. C. (1987a) Impact of natural hydrocarbons on hydroxyl and peroxy radicals at a remote site. J. geophys. Res. 92, 11,879-11,894.

Trainer M., Williams E. J., Parrish D. D., Buhr M. P., Allwine E. J., Westberg H. H., Fehsenfeld F. C. and Liu S. C. (1987b) Models and observations of the impact of natural hydrocarbons on rural ozone. Nature 329, 705-707.

Trainer M., Buhr M. P., Curran C. M., Fehsenfeld F. C., Hsie E. Y., Liu S. C., Norton R. B., Parrish D. D. and Williams E. J. (1991) Observations and modeling of reactive nitrogen photochemistry at a rural site. J. geophys. Res. 96, 3045-3063.

Uno I., Wakamatsu S., Wadden R. A., Konno S. and Koshio H. (1985) Evaluation of hydrocarbon reactivity in urban air. Atmospheric Environment 19, 1283-1293.

Venkatram A., Karamachandani P. K. and Misra P. K. (1988) Testing a comprehensive acid deposition model. Atmospheric Environment 22, 737-747.

Wesely M. L. (1989) Parameterization of surface resistances to gaseous dry deposition in regional-scale numerical models. Atmospheric Environment 23, 1293-1304.

Yokouchi Y. and Ambe Y. (1988) Diurnal variations of atmospheric isoprene and monoterpene hydrocarbons in an agricultural area in summertime. $J$. geophys. Res. 93, $3751-3759$.

Zimmerman P. R. (1979) Testing for hydrocarbon emissions from vegetation leaf litter and aquatic surfaces, and development of a methodology for compiling biogenic emission inventories. EPA Report 450/4-4-79-004.

Zimmerman D., Tax W., Smith M., Demmy J. and Battye R. (1988a) Anthropogenic emission data for the 1985 NAPAP inventory. EPA-600/7-88-022.

Zimmerman P. R., Greenberg J. P. and Westberg C. E. (1988b) Measurements of atmospheric hydrocarbons and biogenic emission fluxes in the Amazon boundary layer. $J$. geophys. Res. 93, 1407-1416. 